\title{
Model Pembelajaran Kolaborasi Meningkatkan Partisipasi Siswa,Keterampilan Sosial, dan Prestasi Belajar IPS
}

\author{
Muhammad Zainuddin \\ SMP Negeri 2 Gresik \\ zainuddin.pak zen@yahoo.com
}

\begin{abstract}
:
Collaboration Learning Model to Increase Participation, Social Skill, and Social Study Achievement. Purpose of this class action research is for increase: (1) student paticipation in learning social study, (2) student social skill; (3) social study learning achievement, and social, (4) student positive response toward collaboration learning application. Prosedure of this class action research include three cycles, and every cycle consists of planning, implementation, observation, and replection. This action research is done in SMPN 2 Gresik, with the subject is students class IXC amoumt 32 people who consist of 9 boys and 23 girls. The research result shows that collaboration learning application can increase: (1) student participation in learning social study, (2) student social skill; (3) social study learning achievement, and (4) student has positive response toward collaboration learning model.
\end{abstract}

\begin{abstract}
Abstrak
Model Pembelajaran Kolaborasi untuk Meningkatkan Partisipasi Siswa, Keterampilan Sosial, dan Prestasi Belajar IPS. Tujuan penelitian tindakan kelas ini adalah untuk meningkatkan (1) partisipasi siswa dalam pembelajaran IPS, (2) keterampilan sosial siswa, (3) prestasi belajar IPS, dan (4) respon positif siswa terhadap penerapan pembelajaran kolaborasi. Prosedur penelitian tindakan kelas terdiri atas tiga siklus, dan setiap siklus meliputi perencanaan, pelaksanaan, pengamatan, dan refleksi. Penelitian tindakan ini dilaksanakan di SMPN 2 Gresik, dengan subjek siswa kelas IXC berjumlah 32 orang terdiri atas 15 pria dan 17 wanita. Hasil penelitian menunjukkan bahwa penerapan pembelajaran kolaborasi dapat meningkatkan (1) partisipasi siswa dalam pembelajaran IPS, (2) keterampilan sosial siswa, (3) prestasi belajar IPS, dan (4) respon positif siswa terhadap model pembelajaran kolaborasi.
\end{abstract}

Kata kunci: pembelajaran kolaborasi, partisipasi siswa, keterampilan sosial, prestasi belajar

\section{PENDAHULUAN}

Berdasarkan hasil pengamatan yang dilakukan pada siswa kelas IXC ketika diberikan soal-soal yang berkaitan dengan materi pokok: geografi negara berkembang dan negara maju pada semester gasal, nilai rata-rata yang diperoleh hanya 62 dan $45 \%$ dari siswa tidak tuntas belajar. Hal itu menunjukkan masih belum maksimal penguasaan IPS. Penelitian ini memberikan solusi memperbaiki sekaligus meningkatkan mutu proses pembelajaran melalui model pembelajaran kolaborasi diharapkan dapat meningkatkan aktivitas siswa, partisipasi dalam berdiskusi, keterampilan sosial, 
prestasi belajar IPS, dan respon positif siswa terhadap model pembelajaraan kolaborasi.

Beberapa kelebihan model pembelajaran kolaborasi.Pertama, adanya kerja sama dalam kelompok dan untuk menentukan keberhasilan kelompok bergantung pada keberhasilan individu,sehingga setiap anggota kelompok tidak bisa menggantungkan pada anggota yang lain.Kedua, setiap siswa mendapat kesempatan sama untuk menunjang timnya mendapat nilai yang maksimal, sehingga termotivasi untuk belajar. Ketiga, setiap individu merasa mendapat tugas dan tanggung jawab sendiri-sendiri, sehingga tujuan pembelajaran kolaborasi dapat berjalan bermakna dan tujuan pembelajaran dapat dicapai secara maksimal sesuai dengan harapan tujuan pendidikan nasional.

Tugas guru adalah mempermudah siswa untuk belajar, memberikan kondisi yang kondusif yang mampu menciptakan pembelajaran bermakna secara signifikan bagi diri siswa secara holistik, tujuannya untuk kepentingan kelompok meliputi guru, komunitasnya termasuk siswa. Keingintahuan siswa secara bebas, keterbukaan, dan segala sesuatunya dapat digali dan dipertanyakan. Pada akhirnya, tuntutan mutu pendidikan untuk mampu menghasilkan sumber daya manusia yang berkualitas dapat dicapai sesuai dengan harapan kita.

Pengertian kolaborasi sering disamakan dengan kooperasi. Kerja sama yang disebut kooperasi ini adalah sebuah struktur kerja sama dalam bentuk kerja kelompok. Di dalam struktur kerja kooperasi ini terjadi proses-proses interaksi antaranggota kelompok, yang disebut kolaborasi. Kolaborasi merupakan suatu landasan interaksi dan cara hidup seseorang di mana individu bertanggung jawab atas tindakannya, yang mencakup kemampuan belajar dan menghargai serta memberikan dukungan terhadap kelompoknya. Melalui aktivitas itu, dapat diidentifikasi perilaku-perilaku kolaborasi, menempatkan perilaku tersebut dalam urutan yang sesuai, dan pebelajar mendemonstrasikannya. Inti keterampilan kolaborasi adalah kemampuan untuk melakukan tukar pikiran dan perasaan antara pebelajar yang satu sama lainnya pada tingkatan yang sama (Setyosari, 2009).

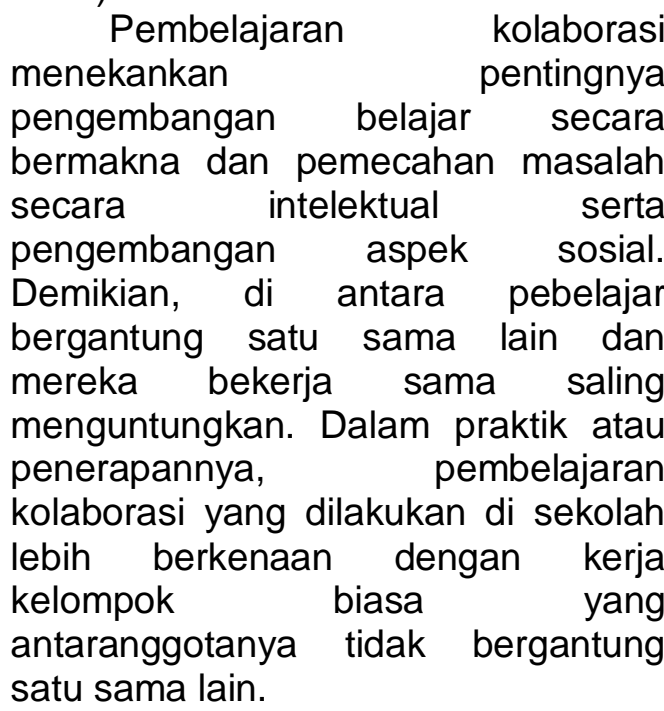

Pembelajaran kolaborasi merupakan sistem pembelajaran yang memberi kesempatan kepada pebelajar untuk bekerja sama dengan yang lain dalam tugas-tugas yang terstruktur. Lebih jauh dikatakan, pembelajaran kolaborasi hanya berjalan kalau sudah terbentuk suatu kelompok atau suatu tim yang di dalamnya siswa bekerja sama secara terarah untuk mencapai tujuan yang sudah ditentukan dengan jumlah anggota kelompok pada umumnya terdiri atas 4-6 orang (Lie, 2002; Mustaji, 2010). 
Pembelajaran

kolaborasimerupakan suatu model pembelajaran yang saat ini banyak digunakan untuk mewujudkan kegiatan belajar mengajar yang berpusat pada siswa, terutama untuk mengatasi permasalahan yang ditemukan guru dalam mengaktifkan siswa, yang tidak dapat bekerja sama dengan orang lain, siswa yang agresif dan tidak peduli pada yang lain. Model pembelajaran ini telah terbukti dapat dipergunakan dalam berbagai mata pelajaran dan berbagai usia.

Metode belajar kelompok atau lazim disebut dengan metode kolaborasi merupakan suatu metode mengajar di mana siswa disusun dalam kelompok-kelompokpada waktu menerima pelajaran atau mengerjakan soal-soal dan tugas-tugas (Isjoni, 2007). Belajar kelompok itu efektif kalau setiap individu merasa bertanggung jawab terhadap kelompok, siswa turut berpartisipasi dan bekerja sama dengan individu lain secara efektif, menimbulkan perubahan yang konstruktif pada kelakuan seseorang dan setiap anggota aman dan puas di dalam kelas (Mustaji, 2010). Belajar kelompok dibentuk dengan harapan para siswa dapat berpartisipasi aktif dalam pembelajaran (Lie, 2002).

Beberapa ciri pembelajaran kolaborasi (Isjoni, 2007). Pertama, setiap anggota memiliki peran. Kedua, terjadi hubungan interaksi langsung di antara siswa. Ketiga, setiap anggota kelompok bertanggung jawab atas belajarnya dan juga teman-teman sekelompoknya. Keempat, guru membantu mengembangkan keterampilan-keterampilan

interpersonal kelompok. Kelima, guru hanya berinteraksi dengan kelompok saat diperlukan.

Model pembelajaran kolaborasi lebih menekankan pembangunan makna oleh pebelajar dari proses sosial bertumpu pada konteks belajar. Pembelajaran kolaborasi lebih jauh dan mendalam dibandingkan hanya sekedar kooperasi. Dasar model pembelajaran kolaborasi adalah interaksional yang memandang belajar sebagai suatu proses membangun makna melalui interaksi sosial (Thobroni \& Mustofa, 2011).

Prosedur

pembelajaran

kolaboratsi yang dijadikan pijakan dalam pengem-bangan model adalah prosedur dari Mann (2003) yang terdiri atas empat tahapan. Pertama, tim belajar terdiri antara 3-5 orang. Kedua, tim belajar memulai kerja dengan kegiatan penyamaan persepsi tentang proses belajar yang akan dilakukan. Ketiga, tim beranggotakan mereka yang memiliki tingkat pengetahuan berbeda, latar belakang yang berbeda, dan pengalaman yang berbeda. Perbedaan ini akan membawa dampak positif dalam pembelajaran (setiap individu membawa kekuatan bagi timnya, setiap anggota tim bertanggung jawab pada kekuatan mereka, anggota tim yang tidak nyaman dengan mayoritas harus didukung dan secara proaktif dikuasakan untuk memberikan masukan). Keempat, melakukan komitmen anggota untuk mencapai suatu tujuan.

Partisipasi berarti prakarsa, peran aktif dan keterlibatan semua pelaku siswa dalam mempelajari IPS (Adisasmita, 2008; Sukidin, 2002) mengemukakan bahwa partisipasi siswa merupakan suatu tingkat sejauhmana peran siswa melibatkan diri di dalam kegiatan dan menyumbangkan tenaga dan pikirannya dalam pelaksanaan kegiatan tersebut. Partisipasi siswa dalam belajar diartikan kegiatan atau keadaan mengambil bagian dalam suatu aktivitas pembelajaran IPS 
untuk mencapai suatu kemanfaatan secara optimal.

Prestasi belajar IPSmerupakan kemampuan menuntaskan dalam arti memahami atau menguasai materi minimal pada mata pelajaran IPS yang ditunjukkan dari hasil ulangan harian siswa dengan standar ketuntasan belajar minimal yang ditentukan guru. Prestasi belajar siswa setelah mengikuti kegiatan belajar mengajar dengan kriteria ketuntasan minimal pada mata pelajaran IPS.

Pengertian prestasi adalah rumusan hasil yang telah dicapai oleh seseorang setelah melakukan atau menyelesaikan suatu pekerjaan. Prestasi belajar ini tampak dalam tingkah laku individu, baik dari segi kognitif, afektif maupun psikomotorik. Slameto (2003), menyatakan "prestasi belajar adalah suatu kemajuan yang merupakan kesimpulan konsep atau nilai yang dapat diterapkan dalam hidup, situasi atau pengalaman baru, pergaulan dengan teman, perilaku di sekolah, di rumah ataupun di dalam lingkungan tetangga". Dengan demikian pengertian prestasi belajar dapat disimpulkan sebagai hasil yang dicapai siswa dalam proses belajar di sekolah yang berupa penguasaan pengetahuan, kecakapan hidup, dan sikap yang umumnya dinyatakan dalam bentuk angka.

Prestasi belajar semakin terasa penting karena mempunyai beberapa tujuan.Pertama, prestasi belajar menunjukkan indikator kualitas dan kuantitas pengetahuan yang telah dikuasai siswa. Kedua, prestasi belajar sebagai lambang pemuasan hasrat ingin tahu. Hal ini didasarkan asumsi bahwa hal ini sebagai tendensi keingintahuan dan merupakan kebutuhan umum pada manusia. Ketiga, prestasi belajar sebagai bahan informasi dalam inovasi pendidikan. Asumsinya bahwa prestasi belajar dapat dijadikan pendorong bagi siswa untuk meningkatkan ilmu dan berperan sebagai umpan balik dalam meningkatkan mutu pendidikan. Keempat,prestasi belajar sebagai indikator internal dari suatu lembaga pendidikan, indikator internal dalam artian bahwa prestasi belajar dapat dijadikan indikator tingkat produktivitas suatu lembaga pendidikan. Kelima, prestasi belajar dapat dijadikanindikator terhadap daya serap ataukecerdasan siswa. Dalam proses belajar mengajar, siswa merupakan masalah yang pertama dan utama, karena siswalahyang diharapkan dapat menyerap seluruh materi pelajaran yang diprogramkan dalam kurikulum.

Berdasarkan uraian di atas maka permasalahan penelitian ini dirumuskan sebagai berikut: (1) bagaimanakah partisipasi siswa dalam mempelajari IPS, ketika diimplementasikan pembelajaran kolaborasi?; (2) apakah implementasi pembelajaran kolaborasi dapat meningkatkan keterampilan sosial siswa?; (3) apakah implementasi pembelajaran kolaborasi dapatmeningkatkan prestasi belajar IPS?; dan (4) bagaimanakah respon siswa terhadap model pembelajaran kolaborasi?

\section{METODE}

Penelitian dilakukan di SMP Negeri 2 Gresik pada semester gasal tahun pelajaran 2016/2017. Subjek penelitian ini adalah siswa kelas IXC dengan jumlah siswa sebanyak 32 siswa. Jumlah siswa laki-laki sebanyak 15 siswa, sedangkan siswa perempuan berjumlah 17 siswa. Dipilihnya kelas IXC sebagai subjek penelitian tindakan ini dengan alasan bahwa sebagian siswa di kelas ini kurang bergairah belajar, motivasi 
belajar rendah, aktivitas belajar siswa pasif, dan rendahnya prestasi belajar kalau dibandingkan dengan kelaskelas lainnya.

Penelitian ini dirancang dengan menggunakan penelitian tindakan kelas, yaitu penelitian yang dilakukan oleh guru di dalam kelasnya sendiri melalu irefleksi diri, dengan tujuan untuk memperbaiki kinerjanya sebagai pendidik sehingga kualitas proses dan hasil belajar siswa menjadi meningkat (Wardhani, 2007). Penelitian tindakan kelas merupakan suatu proses investigasi terkendali yang berdaur ulang dan reflektif mandiri yang dilakukanoleh guru bertujuan untuk memperbaiki sistem, cara kerja, proses, isi, kompetensi, atau situasi pembelajaran.

Status guru dalam penelitian tindakan kelas ini adalah sebagai pengamat atau peneliti sekaligus sebagai pelaksana tindakan. Secara umum pelaksanaan akan dilakukan selama tiga siklus yang pada siklusnya diterapkan tindakan tertentu. Setiap siklus aktivitas penelitian dilakukan melalui prosedur penelitian yang berupa: (1) perencanaan tindakan, (2) pelaksana antindakan, (3) pengamatan tindakan, dan (4) refleksi.

Penelitian tindakan kelas ini menggunakan teknik pengumpulan data antara lain: (1) metode observasi yaitu dilakukan untuk memperoleh data dari siswa yang sedang melakukan tindakan pembelajaran materi pokok: geografi negara berkembang dan negara maju melalui pembelajaran kolaborasi, (2) metode angket, yaitu digunakan untuk mengukur respon siswa. Daftar pertanyaan diberikan kepada siswa untuk mengetahui gambaran permasalahanyang dihadapi, dan (3) metode tes, yaitu dilakukan untuk mengetahui ketuntasan belajar setelah siswamengikuti serangkaian kegiatan pembelajaran.

Berdasarkan pengamatan

kondisi awal kelas IXC nilai rata-rata ulangan harian di bawah kelas IX lainnya. Dari data-data yang diperoleh yaitu data prestasi belajar IPS, partisipasi siswa, dan keterampilan sosial siswa merupakan data utama dalam penelitian ini, sedangkan data respon siswa adalah data pendukung. Data tersebut dianalisis dengan teknik deskripsi dan persentase.

\section{HASIL PENELITIAN DAN PEMBAHASAN}

Keadaan awal sebelum implementasi pembelajaran kolaborasi pada mata pelajaran IPS yang membahas materi pokok: geografi negara berkembang dan negara maju, menggunakan metode pembelajaran konvensional yaitu ceramah, penugasan dan tanyajawab. Hasil tes ulangan harian adalah rata-rata nilai 65 ketuntasan secara klasikal 62\%, dua belassiswa yang tidak tuntas.

Penelitian tindakan kelas pada siklus I ini siswa mengkaji materi pokok: geografi negara berkembang 1. Perangkat pembelajaran yang disiapkan meliputi, desain pembelajaran, bahan ajar IPS,dan soal evaluasi. Dalam RPP dirancang dengan kegiatan pendahuluan yang meliputi menjelaskan tujuan pembelajaran memberikan motivasi, dan apersepsi kepada siswa. Kegiatan inti yang direncanakan antara lain: menjelaskan materi geografi negara berkembang 1, membentuk kelompok, setiap kelompok menyusun soal, setiap berdiskusi menjawab pertanyaan, dan setiap kelompok secara bergilir melakukan presentasi. Sebelum kegiatan pembelajaran ditutup pada siklus I ini dilakukan apresiasi terhadap setiap kelompok yang sudah melakukan presentasi. 
Kegiatan yang dilakukan guru pada saat pembelajaran antara lain menyampaikan informasi tentang materi geografi negara berkembang 1 , siswa membentuk kelompok, kegiatan strategi pesta pertanyaan diarahkan untuk melatih siswa bekerja sama dalam membuat dan menjawab pertanyaan dari materi IPS yang ditentukan. Guru membimbing siswa dalam mempelajari beragam sumber, membuat soal, berdiskusi, menjawab soal, dan mengawasi kegiatan siswa. Guru memberikan penghargaan kepada kelompok yang memperoleh skor atau nilai tertinggi. Selanjutnya ditutup dengan menyimpulkan bersamadan memberi tugas rumah untuk minggu depan.

Hasil pengamatanmenunjukkan bahwa partisipasi siswa dalam proses pembelajaran rata-ratanya mencapai $75 \%$. Dari data partisipasi siswa tersebut kegiatan yang paling menonjol yang dilakukan sebagian besar siswa adalah kegiatan membaca dan mencatat materi penting mencapai $94 \%$ dan kegiatan melakukan kerja sama kooperatif sebesar $100 \%$. Keterampilan sosial siswa dalam melaksanakan diskusi kolaborasi pada siklus I yaitu kemampuan siswa untuk bekerja sama sedikit, mendengarkan dengan aktif banyak, merespon pendapat teman sedang, mengambil giliran beride sedang, mempresentasikan hasil kerja kelompok sedang.

Hasil ulangan harian prasiklus dan siklus I menunjukkan adanya kenaikan jumlah siswa yang tuntas hasil belajarnya. Nilai rata-rata yang dicapai pada ulangan harian awal sebesar 65 sedangkan pada siklus I mencapai 75. Ketuntasan klasikal pada ulangan harian awal hanya mencapai $62 \%$, pada siklus I ini meningkat menjadi $88 \%$, tetapi ada tiga siswa belum tuntas
Hasil pengamatan yang telah dilakukan dapat dievaluasi dan direfleksi dengan ditemukan hambatan yaitu: (1) sebagian siswa ada yang terlalu mendominasi dalam kerja sama, sehingga kesempatan teman untuk ikut kerja sama masih belum maksimal, (2) penjelasan guru pada materi pelajaran dianggap cukup menyita waktu sehingga perlu dikurangi pada siklus berikutnya, dan (3) ada tiga siswa yang belum tuntas.

Pada siklus II materi yang dibahas adalah geografi negara berkembang 2 . Perangkat yang disiapkan meliputi desain pembelajaran, bahan ajar IPS, dan lembar kegiatan siswa. Berdasarkan refleksi pada siklus I maka perlu ada dua tindakan, yaitu waktu untuk memberikan penjelasan kepada siswa perlu dikurangi dan kesempatan untuk memberikan giliran kepada siswa lain dalam melakukan kerja sama masih dapat dimaksimalkan.

Tindakan guru pada siklus II ini telah sesuai dengan yang direncanakan pada desain pembelajaran sehingga tidak banyak memakan waktu. Sebelum kegiatan pembelajaran selesai diadakan apresiasi terhadap setiap kelompok berhasil melakukan presentasi, dan pemberian penghargaan kepada kelompok yang memperoleh nilai terbaik.

Hasil pengamatan pada siklus II menunjukkanpartisipasi siswa pada siklus I mencapai $75 \%$, pada siklus II meningkat menjadi $85 \%$. Keterampilan siswa dalam melaksanakan diskusi kolaborasi meliputi: kemampuan siswa untuk bekerja sama banyak, mendengarkan dengan aktif banyak, merespon pendapat teman sedang, mengambil giliran mengemukakan pendapat banyak, mempresentasikan hasil kerja sama banyak. 
Hasil ulangan harian siklus II menunjukkan adanya kenaikan jumlah siswa yang tuntas belajarnya. Pada siklus I ketuntasan belajar secara klasikal $88 \%$, siklus II naik menjadi $96 \%$ dan nilai rata-rata siklus I sebesar 75, siklus II menjadi 85 . Siswa yang tidak tuntas pada siklus II ada dua siswa.

Refleksi pada siklus II ini ditemukan permasalahan yaitu: (1) penyediaan buku paket IPS bagi siswa diperlukan kerana banyak siswa yang belum memiliki buku paket, karena itu siswa yang tidak memiliki buku paket dianjurkan untuk pinjam di perpustakaan sekolah, dan (2) masih ada dua siswa yang belum tuntas belajarnya. Bimbingan pada siswa yang belum tuntas pada saat proses pembelajaran IPS dimaksimalkan.

Pada siklus III ini materi yang diajarkan adalah geografi regional negara maju. Perangkat pembelajaran yang disiapkan meliputi desain pembelajaran, bahan ajar, dan lembar kegiatan siswa. Rencana pembelajaran dan pelaksanaan pesta pertanyaan, secara garis besar masih sama dengan siklus I dan II. Namun berdasarkan refleksi siklus II terdapat dua siswa yang belum tuntas, pada siklus III ini siswa tersebut diberikan bimbingan yang lebih baik secara khusus. Penyediaan buku paket IPS dilengkapi dari pinjaman perpustakaan setiap siswa satu buku.

Hasil pengamatan pada siklus III menunjukkan ada peningkatan. Partisipasi siswa dalam proses pembelajaran IPS meningkat dari $79 \%$ pada siklus II menjadi $86 \%$ pada siklus III. Keterampilan siswa dalam melaksanakan model pembelajaran kolaborasi mencapai 100\%. Data respon siswa yang diperoleh melalui angket terhadap model pembelajaran kolaborasi pada mata pelajaran IPS rata-rata mencapai $94 \%$.
Prestasi belajar IPS mengalami peningkatan secara signifikan ditunjukkan dengan nilai rata-rata pada siklus II sebesar 85, pada siklus III naik menjadi 95. Persentase ketuntasan klasikal naik dari 94\% menjadi 100\%.Hasil ulangan harian siswa pada ulangan harian awal 65, sedangkan ulangan harian akhir mencapai nilai 85 dengan ketuntasan belajar klasikal 100\%.

Data respon siswa yang diperoleh melalui angket terhadap pembelajaran kolaborasi pada mata pelajaran IPS rata-rata mencapai $94 \%$. Hal ini membuktikan bahwa model pembelajaran kolaborasi dengan strategi pesta pertanyaan direspon positif oleh siswa dalam membangun perilaku konstruktivis.

Pada siklus III ini menunjukkan adanya peningkatan dari berbagai hal, tetapi berdasarkan refleksi siklus III ini masih ditemukan permasalahan yaitu: (1) buku referensi siswa dan guru kurang. Karena itu, pengadaan buku referensi lain selain buku paket sangat diperlukan, dan (2) saat presentasi hasil diskusi kurang tersedianya waktu yang cukup. Untuk ketercapaian tujuan maka perlu adanya manajemen waktu atau penembahan waktu agar kegiatan pembelajaran dapat berlangsung lebih maksimal. Implementasi pembelajaran kolaborasi mampu meningkatkan prestasi belajar siswa. Peningkatan penguasaan materi geografi negara berkembang dan maju dapat dilihat dari hasil kuis dari siklus I, siklus II dan siklus III bahkan dapat dilihat dari hasil ulangan harian. Hal ini didukung keunggulan pembelajaran kolaborasi, di antaranya:(1) prestasi belajar lebih tinggi; (2) pemahaman lebih mendalam; (3) belajar lebih menyenangkan; (4) mengembangkan keterampilan kepemimpinan; meningkatkan sikap positif; 
meningkatkan harga diri; (7) belajar secara inklusif; (8) merasa saling memiliki; dan (9) mengembangkan keterampilan masa depan (Setyosari, 2009:)

Model pembelajaran kolaborasi dapat membuat kemajuan besar para siswa ke arah pengembangan sikap, nilai, dan berpartisipasi dalam komunitas mereka dengan cara-cara yang sesuai dengan tujuan pembelajaran IPS. Howard (1999) berpendapat bahwab hal ini dapat tercapai karena tujuan utama pembelajaran kolaborasi adalah untuk memperoleh pengetahuan dari sesama temannya. Lie (2002) mengatakan bahwa pengetahuan itu tidak lagi diperoleh dari gurunya, tetapi dari belajar kelompok. Seorang teman haruslah memberikan kesempatan kepada teman yang lain untuk mengemukakan pendapatnya dengan cara menghargai pendapat orang lain, saling mengoreksi kesalahan, dan saling membetulkan sama lainnya.

Model pembelajaran kolaborasi dapat meningkatkan partisipasi siswa dan keterampilan sosial dalam mempelajari atau mengakaji materi esensial dan sulit IPS. Di samping itu, strategi ini memotivasi atau membuat kemajuan besar para siswa ke arah pengembangan sikap, nilai, dan berpartisipasi dalam komunitas mereka dengan cara-cara yang sesuai dengan tujuan pembelajaran IPS. Hal ini dapat tercapai karena tujuan utama pembelajaran kolaborasiadalah untuk memperoleh pengetahuan dari sesama temannya. Pengetahuan itu tidak lagi diperoleh dari gurunya, tetapi dari belajar kelompok. Seorang teman haruslah memberikan kesempatan kepada teman yang lain untuk mengemukakan pendapatnya dengan cara menghargai pendapat orang lain, saling mengoreksi kesalahan, dan saling membetulkan sama lainnya. Demikian, prestasi belajar siswa pada mata pelajaran IPS dapat meningkat secara signifikan.

\section{SIMPULAN DAN SARAN}

Simpulan yang dapat diambil dari penelitian ini sebagai berikut. Partisipasi siswa selama mengikuti kegiatan pembelajaran IPS meningkat,karena sudah poses belajar mengajar menjadi lebih berpusat kepada siswa. Keterampilan sosial siswa mengalami peningkatan. Prestasi belajar IPS mengalami peningkatan secara signifikan. Respon positif siswa terhadap pembelajaran kolaborasi.

Berkaitan dengan simpulan di atas, guru IPS dan sekolah disarankan:

menerapkanpembelajaran kolaborasi, dan (2) menyediakan sarana pendukung kegiatan pembelajaran yang berupa sumber belajar, misalnya buku paket IPS dan media pembelajaran berupa peta dan atlas bahkan menggunakan laboratorium IPS.

\section{DAFTAR RUJUKAN}

Adisasmita, R. 2008. Membangun Desa Partisipatif. Yogayakarta: Graha IImu.

Abimanyu. $1995 . \quad$ Upaya Meningkatkan Partisipasi Siswa dalam Proses Pembelajaran. Jakarta: Alumni.

Howard, S.A. 1999. Guiding Collaborative Teamwork In The Classroom. Effective Teaching, 10(5): 11-27.

Isjoni. 2007. Cooperative Learning. Bandung: Alfabeta.

Lie, A. 2002. Cooperative Learning. Jakarta: Gramedia.

$\begin{array}{lrrr}\text { Fadjar, } & \text { A. } & \text { M. } & 2005 .\end{array}$ 
kan. Jakarta: Rajawali Pers.

Mann, S.T. 2003. Study Guides and Strategies: Cooperative \& Collaborative Learning, http://www.studygs.net/coo plearn.htm. Diakses, 10 Juni 2013.

Mustaji. 2010. Pengembangan ModelPembelajaranBerba sisMasalahdenganPolaBel ajarKolaborasi (Model PBMPK). JurnalPendidikan\& Pembelajaran,17(2): 187200.

Setyosari, P. 2009. Pembelajaran Kolaborasi: Lndasan untuk Mengembangkan

Keterampilan Sosial, Rasa Saling Menghargai, dan Tanggung Jawab. Pidatojabatan guru besar bidang ilmu teknologi pembelajaran pada Fakultas IImuPendidikan disampaikan dalam Sidang Terbuka Senat Universitas NegeriMalang.

Slameto. 2003. Belajar dan Faktorfaktor Mempenmgaruhinya. Jakarta: Rineka Cipta.

Sukidin dkk. 2002. Penelitian Tindakan Kelas. Surabaya: Insan Cendekia.

Supriatna, N. 2005 Mengajarkan Keterampilan Sosial yang Diperlukan Siswadi EraGlobal. Jurnal Pendidikan IImu Sosial, I(19):12-20.

Syah, M. 2001. Psikologi Belajar. Jakarta: Bumi Aksara.

Thobroni, M. danMustofa, A. 2011. Belajar\&PembelajaranPen gembanganWacanadanPr aktikPembelajarandalamP
embengunanNasional.

Yogyakarta: AR-RUZZ MEDIA.

Wardhani, IGAK. 2007. Penelitian Tindakan Kelas. Jakarta: Universitas Terbuka. 